\title{
TEAM BUILDING DYNAMICS: AN APPLICATION TO MBA STUDENTS
}

\author{
Beatriz Andres, Raquel Sanchis, Raul Poler \\ Research Centre on Production Management and Engineering (CIGIP). \\ Universitat Politècnica de València (UPV) (SPAIN)
}

\begin{abstract}
This paper introduces the concept of team building dynamics for teaching management of high performance teams. A set of methodologies for application, using team building dynamics is proposed and described, by considering also all the steps to follow by the students in order to properly carry out each team building dynamic. Examples of applications in practical classes devoted to MBA students are presented. Finally, a discussion about how the proposed team building dynamics can facilitate compact teamwork is described. The importance of future MBA students, to know the main skills of a good manager, is one of the objectives to achieve in the university education process.
\end{abstract}

Keywords: team building dynamics, management, high performance equipment, emotional and social learning, leadership and teamwork.

\section{INTRODUCTION}

The Master's Degree of Business and Administration has associated a set of basic/general and specific competencies that the students have to achieve in order to obtain the MBA title.

The general competencies are summarised below:

1 Leadership capacity for business management

2 Ability to organize and plan for business management

3 Critical reasoning ability for business management

4 Ability to make decisions in business management environments

5 Possess and understand knowledge that provides a basis or opportunity to be original in the development and/or application of ideas, often in a business context

6 Apply the knowledge acquired and develop the ability to solve problems in new or unfamiliar environments within broader (or multidisciplinary) contexts related to the business area of study

7 Integrate knowledge and face the complexity of making judgments based on information that, being incomplete or limited, includes reflections on social and ethical responsibilities linked to the application of knowledge and judgments

8 Communicate conclusions, knowledge and ultimate reasons that sustain to specialized and non-specialized audiences in a clear and unambiguous way

9 Learn skills that allow them to continue studying in a way that will be largely self-directed or autonomous.

The specific competencies are briefly listed below:

1 Ability to lead innovation processes and develop new business opportunities in a global environment

2 Ability to design the plan of globalization, internationalization or internationalization of operations of a company or organization.

3 Ability to efficiently manage organizations in complex, dynamic and highly competitive environments, through the definition and elaboration of strategic plans, so that they are sustainable from an economic, environmental and social point of view

4 Ability to analyse and interpret economic-financial information as a tool for the allocation of assets, definition of investment policies and selection of financing sources from the point of view of liquidity, risk and profitability. 
5 Ability to design, organize and develop the operations strategy based on capacity decisions, supply network and process technology

6 Ability to develop the necessary skills for the exercise of effective leadership of teams of people

7 Ability to search, analyse and select information in the sources, agencies and the most effective means to help the processes of creating and managing of companies

8 Ability to develop entrepreneurial skills to develop economically, socially and environmentally sustainable business plans, which efficiently integrate the functional areas of the company.

9 Ability to simulate business activity and coordinate the different business processes

The skills and capabilities above listed, and marked in bold, are the ones in which the paper is focused on. These skills marked in bold correspond to the application of team building dynamics in MBA students.

On the other hand, the Universitat Politècnica de València, in which this work is developed, is currently involved in the incorporation of transversal skills into the curriculum of graduates and master degree graduates. For the students, this is an opportunity to acquire transferable skills and accredit their training in these skills. While for the UPV, the inclusion of transversal skills is considered as valuable in terms of improvement qualifications, and national and international accreditations. UPV considers the importance of defining transversal competences in addition to the general and specific competences associated to each subject in each of the degrees offered by the university (previously listed for the Master Degree of Business and Administration, MBA).

Thirteen are the transversal skills considered by the UPV. Initially, the entity responsible for the degree has established the relations between the degree and the thirteen transversal skills, considering the definition of each skill and the objectives pursued by each degree. Next, the academic committee of the degree has established checkpoints taking into account, on the one hand, the relation with the transversal skills set by the entity responsible for the degree and, on the other hand, the level of contribution of each subject at each skill defined in the degree-teaching guide. The UPV intends that, instead of each subject assesses independently each transversal skill, which has been initially defined as a control point, an holistic approach is adopted in the definition of subjects checkpoints, design subject for evaluation of transversal skills and evaluation of results (Andres et al., 2016) [1].

The transversal competences, object of study in this paper, are associated with (i) innovation, creativity and entrepreneurship; (ii) teamwork and leadership; and (iii) effective communication. The basic/general and specific skills marked in bold, jointly with the transversal competences selected, are the ones that are going to be addressed through the application of the team building dynamic methodologies, proposed in this paper.

Considering the importance of the transversal competencies defined by the UPV, and its strong relation in the application of team building dynamic methodologies; the remaining of the paper is organised as follows: section 1.1 describes in detail all the transversal competences addressed in the UPV, emphasizing the ones that are related with the object of study of the present paper.

\subsection{Transversal competences related with the development of management skills and management of high performance teams}

Master graduates and employers do not hesitate to emphasize the great importance that transversal and generic skills have in the professional performance of graduates. As a result, new degrees and postgraduate titles explicitly incorporate the requirement that students have to train in transversal skills, evaluating their level of achievement [1]. An overview of each of the traversal skills, related with the with the development of management skills and management of high performance teams, is provided next:

Innovation, creativity and entrepreneurship. Innovation is understood as the ability to provide satisfactory answers to the personal, organizational and social needs, modifying processes and/or results to generate new value response. In turn, the development of this skill requires both thinking in a different manner to provide different perspectives (creativity), and the commitment of certain resources on his/her own initiative, in order to explore an opportunity, assuming the risk that this entails (venture). 
Teamwork and leadership. Teamwork involves creating and developing a climate of mutual trust between components that allows working responsibly and cooperatively. The most appropriate term to describe this situation is "sharing": sharing knowledge, commitment and responsibility. It involves the distribution of tasks and roles and the respect of the norms and rules established by and for the group.

Effective communication. Communicate effectively means having developed the ability to transmit knowledge and express ideas and arguments in a clear, rigorous and convincing way, both orally and in writing, using the appropriate resources properly and adapting to the circumstances and the type of audience.

One of the most valuable competences included in the curriculum of the Master's Degree in Business and Administration is the development of management skills and management of high performance teams. As afore mentioned, these transversal competences are

The remaining of the paper is organised as follows: Section 2 introduces the six team building dynamics selected for this paper. A brief description of each methodology is included, and a table comparing of all the dynamics is build. Section 3 summarises the potential results obtained from the application of the six methodologies, reinforcing the set of relevant areas and concepts in the context of managing skills and managing high performance team. Finally, the conclusions of the paper are discussed in section 4 .

\section{METHODOLOGY}

The objective of the laboratory practice will be to carry out different activities and dynamics of Team Building such as the Post-it, Marshmallow Challenge, Mecano Formula1, Lego, Film Festival and Apollo 13 Challenge. With all these methodologies you the MBA students will practice different management methods of leadership, work team, motivation and conflict resolution. In table 1 in can be seen the six team building dynamics selected (in the first row), for its application in the context of management skills and management of high performance teams. The second row indicates if the selected dynamics require physical activity or not; this can be useful for selecting the dynamic in a group with diversity of people. The third row indicates the place in which the teachers can perform the team building dynamic; the place can be also a constraint if technique has to be performed outdoors. The forth column list the benefits associated to each proposed methodology. The fifth column specifies the time require performing the dynamic. The sixth column refers to the minimum number of participants to properly carry out the activity with the team building dynamic. Finally, the seventh column indicates the areas in which the each proposed technique can be held.

\subsection{Post-lt}

Creation of a mosaic made of Post-its in a time limit with a commitment by each participant. The students can create the logo of the company, the image of a key product; the students' imagination is the limit (see figure 1a).

\subsubsection{Post It Wars}

An energy activity, key and focus to awaken the spirit of teamwork. Each team will compete to design and create the best mosaic in a given time $(30 \mathrm{~min})$. The perfect activity to carry out a meeting where the active participation of all is key. The activity allows to (i) think outside the work position, (ii) land in a creative process, (iii) plan, (iv) run and see a masterpiece done in front of the students eyes, and (v) have fun and integration.

\subsubsection{Post Your Promises}

Used to close a unified activity and common end, with commitments. An activity that proves that with the commitment of each member, the greatest objectives can be achieved. The group will have a time limit to create a predetermined design (company logo, key product image, etc.), with Post-it the group will have to carry their personal commitment. It is a good activity for the closing of a successful meeting. The activity allows to (i) plan and execute, (ii) motivate, (iii) achieve excellence, (iv) achieve a commitment, ( $v$ ) have fun integration, and (vi) see the importance of the participation of each member in the global mission. 


\subsection{Marshmallow Challenge}

The marshmallow challenge is an exercise designed to promote collaboration, creative thinking and communication as a basis for building effective teams. A few years ago, Peter Skillman introduced a design challenge called the marshmallow challenge, and the idea is was simple. Teams of four have to build the highest autonomous structure, with 20 spaghetti, a meter of tape, a meter of rope and a marshmallow. The marshmallow must go on top of everything. And, although it seems easy, it is quite difficult, because it forces people to collaborate very quickly. Since then workshops were organized around the world with students, designers and architects, up to the CEOs of the largest companies. And there is something particular about this exercise that reveals profound lessons about the nature of collaboration. The result of the teams will surprise them, as well as the presentation of the research carried out around the world with different types of equipment. Each team will have only 1 marshmallow, $1 \mathrm{~m}$ of string and adhesive tape, scissors, spaghetti and 18 minutes to raise the marshmallow as high as possible and sustainably (see figure $1 \mathrm{~b}$ ).

\subsection{Mecano, Formula 1}

Divided into teams the teams will receive the same amount of resources and the same objective: to be the most profitable team and several challenges to achieve it (see figure 1c).

\subsubsection{The game}

Each team (teams of 8 to 10 people) will have a clear objective, to have the higher amount of utilities during the season. For this they will participate in several competitions that have an economic remuneration: Best Design Award, Original Photo, Best Announcement and the Grand Prix stellar event. As part of their initial Kit the teams will receive material and money for their purchases. At their disposal they will have a specialized store that sells parts (technical advice, instructions, paper, axles, tires, ...)

\subsubsection{Grand Prix}

It is a relay race where the cars turn the circuit carrying a boat of water, when completing the lap they fill the tank with their number, they return to the Pits and change the driver and engine. The first team to fill your tank wins the race. In each round the participants must exchange helmet and overalls (mandatory for safety). Once the race is over, a debriefing will be carried out to analyze the results, the money of each team will be counted and the winners will be awarded (see figure 1d).

\subsection{Lego}

Workshop based on Legos with 3 main themes: Planning, Communication and Teamwork

Workshop focused on leadership, effective communication and continuous improvement in teamwork, creating the commitment and confidence of each person to achieve the goals. The group work on three-dimensional thinking by creating and constructing metaphors in a fun way to describe real situations that the organization faces on a daily basis (see figure 1d).

\subsubsection{Planning}

Build the highest scoring tower. With the same materials, the teams will have a time limit to build the best tower with Legos. The students may fall several times in the attempt, but they must restart and improve with the experience gained.

\subsubsection{Effective joints}

Build a secret figure. The teams have to make an exact replica of a secret figure. However, the figure is in a restricted area and only one member can see it and communicate to his team as it is.

\subsubsection{Continuous Improvement}

Build an expert figure. An expert can build a complex figure in 5 hours ... but an inexperienced Team in Lego with a High Performance Level must achieve it in a record time. 


\subsection{Film Festival}

The group will be divided into film studios, each of which will create a 20 seconds advertisement short.

\subsubsection{Film Festival}

In this media game, the participants will become, reporters, photographers, editors, actors and writers. The group will be divided into advertising agencies that will be given the subject of a 20 -second advertisement that an important client has commissioned them. That advertisement will participate in the contest for the best commercial short of the year. The teams must split roles for a short period to create the storyboard, guide, create costumes, act and film their advertising short. In the end, prizes will be given to the best advertisements. In this event, the participants will be involved in the products of the company, analyzing their benefits, who is targeted, and the strategy to reach the final customer (see figure 1e).

\subsection{Apollo 13}

A fun workshop that combines basic tips to improve performance and achieve success. A vision of teamwork as a tool for achieving goals (see figure 1f).

In the launching of a space mission, there is no room for error, it is a single opportunity. As challenges become more difficult, success depends on the team rather than on a person, for that reason, NASA has spent years working on the development of teams. The APOLLO 13 workshop is based on the experience experienced by the space shuttle team in a critical situation, requiring teamwork, a lot of communication and commitment to find the solution to the problem in a restricted time. The main activity is the construction and launching of a water rocket, for which the teams will have to build and perfect prototypes, to achieve success. The teams will be very pleased to see their rockets fly, they will learn that like many sciences, one learns to work with different colleagues towards a common goal.

Table 1. Team Building Dynamics: Abstract and Comparison.

\begin{tabular}{|c|c|c|c|c|c|c|}
\hline & Post-lt & $\begin{array}{c}\text { Marshmallow } \\
\text { Challenge }\end{array}$ & $\begin{array}{c}\text { Mecano } \\
\text { Formula1 }\end{array}$ & Lego & Film Festival & $\begin{array}{l}\text { Apollo } 13 \\
\text { Challenge } \\
\end{array}$ \\
\hline $\begin{array}{l}\text { Physical } \\
\text { Activity }\end{array}$ & Low & Low & High & Low & Low & High \\
\hline Place & $\begin{array}{l}\text { Interiors or } \\
\text { Exteriors }\end{array}$ & $\begin{array}{l}\text { Interiors or } \\
\text { Exteriors }\end{array}$ & $\begin{array}{l}\text { Interiors or } \\
\text { Exteriors }\end{array}$ & $\begin{array}{c}\text { Interiors or } \\
\text { Exteriors }\end{array}$ & $\begin{array}{l}\text { Interiors or } \\
\text { Exteriors }\end{array}$ & Exteriors \\
\hline Benefits & $\begin{array}{l}\text { - Teamwork } \\
\text { - Problem } \\
\text { solving } \\
\text { - Integration } \\
\text { - Creativity }\end{array}$ & $\begin{array}{l}\text { - Common } \\
\text { objective } \\
\text { - Collaborati-on } \\
\text { - Team work } \\
\text { - Communi- } \\
\text { cation } \\
\text { - Time manage- } \\
\text { ment }\end{array}$ & $\begin{array}{l}\text { - Team work } \\
\text { - Problems } \\
\text { solution } \\
\text { - Budget } \\
\text { manage- } \\
\text { ment } \\
\text { - Integration } \\
\text { - Creativity }\end{array}$ & $\begin{array}{l}\text { - Planning } \\
\text { - Team work } \\
\text { - Commu- } \\
\text { nication } \\
\text { - Project } \\
\text { manage- } \\
\text { ment } \\
\text { - Integration } \\
\text { and fun }\end{array}$ & $\begin{array}{l}\text { - Planning } \\
\text { - Team work } \\
\text { - Commu- } \\
\text { nication } \\
\text { - Project } \\
\text { manage-ment } \\
\text { - Integration } \\
\text { and fun }\end{array}$ & $\begin{array}{l}\text { - Commu- } \\
\text { nication } \\
\text { - Team work } \\
\text { - Creativity } \\
\text { - Motivation }\end{array}$ \\
\hline Duration & $\begin{array}{c}\text { From } 1 \text { to } 3 \\
\text { hours }\end{array}$ & $\begin{array}{c}\text { From } 30 \text { minutes } \\
\text { to } 1 \text { hour }\end{array}$ & $\begin{array}{c}\text { From } 2 \text { to } 4 \\
\text { hours }\end{array}$ & $\begin{array}{c}\text { From } 1 \text { to } 3 \\
\text { hours }\end{array}$ & $\begin{array}{c}\text { From } 2 \text { to } 3 \\
\text { hours }\end{array}$ & $\begin{array}{c}\text { From } 2 \text { to } 4 \\
\text { hours }\end{array}$ \\
\hline $\begin{array}{l}\text { Partici- } \\
\text { pants }\end{array}$ & $\begin{array}{l}\text { From } 15 \\
\text { people }\end{array}$ & From 15 people & From 15 people & From 15 people & From 15 people & $\begin{array}{c}\text { From } 20 \\
\text { people }\end{array}$ \\
\hline Areas & $\begin{array}{l}\text { - Large } \\
\text { rooms } \\
\text { - Terraces } \\
\text { with shade }\end{array}$ & $\begin{array}{l}\text { - Large rooms } \\
\text { - Terraces with } \\
\text { shade }\end{array}$ & $\begin{array}{l}\text { - Large rooms } \\
\text { - Parking lots, } \\
\text { paved areas } \\
\text { - Around a } \\
\text { pool shade }\end{array}$ & $\begin{array}{l}\text { - Office } \\
\text { - Large rooms } \\
\text { - Terraces } \\
\text { with shade }\end{array}$ & $\begin{array}{l}\text { - Office } \\
\text { - Large rooms } \\
\text { - Terraces with } \\
\text { shade }\end{array}$ & $\begin{array}{l}\text { - Gardens } \\
\text { - Outdoor } \\
\text { installations }\end{array}$ \\
\hline
\end{tabular}




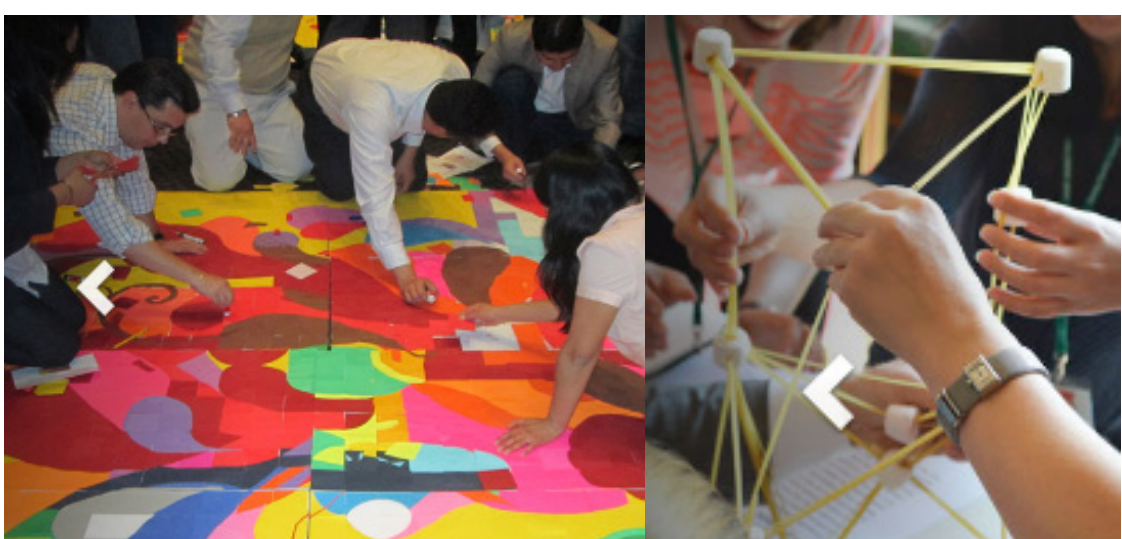

a) Post-it

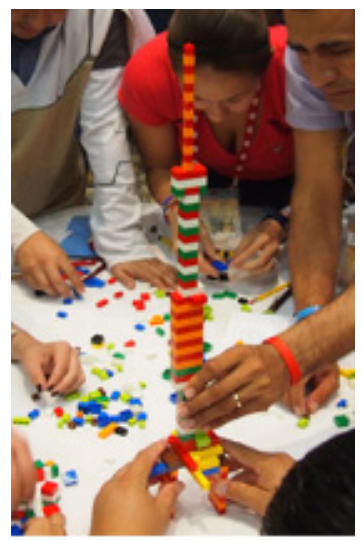

d) Lego b) Marshmallow challenge

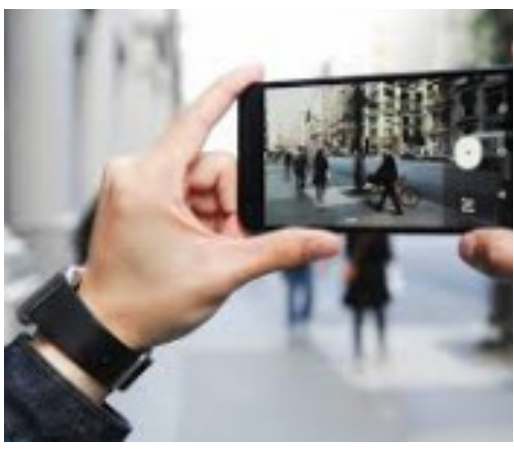

e) Film Festival

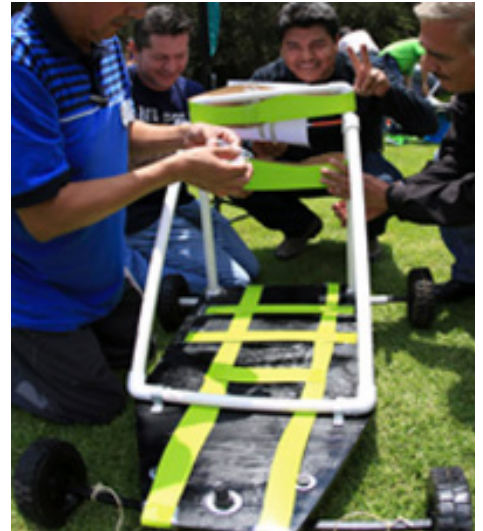

c) Mecano Formula 1

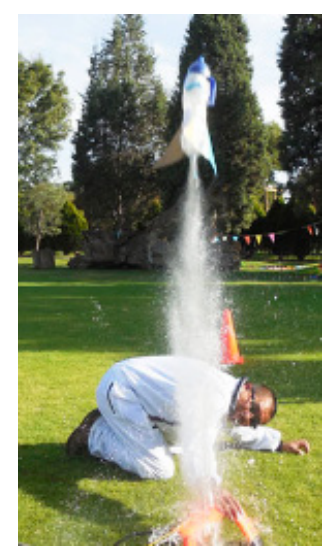

f) Apollo 13 Challenge

Figure 1. Team Building Dynamics

\section{RESULTS}

On the one hand, the application of the methodologies proposed for the team building dynamics will allow reinforcing the following areas and concepts in the context of development of management skills [3] [4] [5] [6]:

- Managerial role and management by competences.

- Roles, roles and managerial skills.

- Competencies and managerial skills.

- Plan, Organize, Manage and Control.

- Decision making and problem solving.

- Prioritize decisions: urgency and importance of a problem.

- The process of decision-making: Retrieve information. Select important data. Define the problem to establish objectives. Teach alternative solutions. Evaluate each of the solutions. Choose the most appropriate alternative. Communicate the decision. Control the results. Introduce correct measures.

- Participation in decisions. Decision making models.

- Factors that influence the decision-making: individual, group, organizational, environmental, group.

- Techniques for decision-making: Consultative technique: the leader decides after consulting the members. Techniques oriented towards the group. Structured decision techniques. Democratic techniques. Techniques oriented to the total participation of the group.

- Communication and negotiation techniques. 
- Metaphors of communication and organization.

- Communication orientation.

- Components and communication process. Information and communication. Communication structure (formal, informal, centralized and decentralized networks).

- Measures to face problems in communication.

- External internal and corporate communication.

- Interpersonal communication tools.

- Electronic communication and electronic networks.

- Negotiation techniques.

- Types of negotiation: objectives, strategies and tactics. Distributive, integrative and mixed negotiation.

- Contextual and dynamic dimensions of the negotiation: the negotiating context. Phases and stages in the negotiation. Prepare and plan. Opening of the negotiation. Discussion of the central issues. Discussion of peripheral issues. Closing.

- Power: relationship, hierarchy, expert, risk.

- What to negotiate and how to negotiate. Competitive negotiator. The cooperative model.

- Time management and meeting management. Thieves of time. Correct time management: Define objectives. Prioritize Schedule time Delegate.

- Reflection: Do we take advantage of our time?

- Specific analysis and diagnosis of the use of time.

- Temporary work organization: biological time, psychological time, social time and work activity. Work schedules.

- Meeting management.

- Coordination of the meeting.

- Communication during the meeting.

- Phases of a meeting: Preparation. Presentation. Development of the meeting. Finished. Follow-up of agreements, decisions and tasks.

- Facilitating roles: moderator, expert counsellor, and accelerator. Negative papers

- Techniques to apply during the meeting: Brainstorming. Guided discussion Debate. Roleplaying game.

- Emotional and social learning. Stress management.

- Emotions, feelings, moods and affective traits.

- Emotions and work behaviour: background of emotions at work. Emotions, planned behaviour and work motivation. Consequences derived from emotions at work.

- Social judgments: Social cognition and social perception. The perception of people.

- Labour socialization and socialization organizational organization. Stages of organizational socialization.

- The agents in the organizational socialization: The organization / direction. The supervisor. The work group and colleagues. Socializing function of the mentor.

- Social organization of work: Roles at work. Activities.

- Stress Management.

- Stress and performance. Labour consequences.

- Prevention and control of work stress.

- Cognitive resources and personal attitudes. Time management. Social skills.

- Strategies and resources used successfully in the face of stress.

- Well-being and health in work contexts. What you can do against stress Take care of the basic needs of the human being. 
On the other hand, the application of the methodologies proposed for the team building dynamics will allow reinforcing the following areas and concepts in the context management of high performance team [3] [4] [5] [6]:

- Leadership and teamwork.

- The exercise of leadership.

- Leaders' traits. Conduct and styles of leaders (participatory).

- Strategic leadership. New leadership.

- Current themes and orientations in management and leadership: Distributed or shared leadership.

- Diversity management. Leadership in different cultures.

- Leadership and knowledge management. Ethical leadership.

- Compatibility between leaders and collaborators.

- A good Leader ... inspires confidence, perseveres in the achievement of its objectives, communicates effectively, understands its personnel, works with objectivity, acts firmly and decisively.

- Work team. Types of work teams.

- Components of teamwork Advantages and disadvantages of work teams and teamwork.

- Elements of the work team (entries): composition of the team. Social structure of the team. Structure of the task. Cultural context.

○ How work teams (processes) work.

- Results of the equipment (outputs): Productive results. Innovations Feasibility of the team. Individual well-being.

- Working groups: Formal and informal groups. Teamwork. The effectiveness of work teams

- Work teams management.

- Motivation of the collaborators.

- Human motivation.

- Main theoretical approaches in the study of motivation. Reflections on Maslow's theory.

- Work motivation: concept.

- How motivation occurs.

- Mechanisms of adjustment to frustration.

- Main theoretical approaches in the study of work motivation.

- Performance: Conceptual aspects.

- Conflict resolution

- Definition of conflict. Types of conflict The dynamics of conflict.

- Conflicts in communication.

- Creative vision of organizational conflicts.

- Models on organizational conflict.

- Causes of conflicts. Factors related to the conflict: Power relations. Communication processes. Intergroup relations Structure, norms and organizational reward systems. Perception of justice. Individual differences.

- Conflict management: Functional and dysfunctional aspects of the conflict. The effective management of conflict. A model of effective conflict management.

- Phases in the resolution of conflicts: Evaluation. Acceptance. Attitude. Action. Analysis.

- How to solve a conflict Types of conflicts and resolution strategies. 


\section{CONCLUSIONS}

Conclusions are provided, considering the utility and the usefulness of the proposed team building dynamics, for supporting the MBA students' management skills and management of high performance teams, in different areas of business and administration. To this regard, MBA students will take advantage of the application of the proposed techniques and dynamics for managing and working in groups (teamwork).

The six proposed team building dynamic (Post-it, Marshmallow Challenge, Mecano, Lego, Film Festival and Apollo 13 Challenge) helps students with the management skills, which are very important for the students' future profession. The paper puts in order ideas, and shows different views of the team building dynamics. The advantages and benefits of using these techniques are summarised in Table 1 and Section 3, and go from Teamwork, to Problem solving, integration, creativity, Common objective, collaboration, communication, time management, budget management, planning, to project management.

\section{REFERENCES}

[1] Andres, B., Sanchis, R., Poler, R.,"Decision-making in teamworks: sticky notes tool for degree students", Proceedings of ICERI conference, 2016. ISBN: 978-84-617-5895-1.

[2] http://www.teams.com.mx/dinamicasdeteambuilding.html

[3] Núñez, A. Núñez, A., Puchol, L., Ongallo, C., Martín, M. a J.; Puchol, I., Sánchez, G. "El libro de las habilidades directivas" Madrid : Díaz de Santos, D.L. 2010. $3^{\mathrm{a}}$ ed.

[4] Alcover de la Hera, C.M., Gil Rodríguez, F. "Introducción a la psicología de las organizaciones" Madrid: Alianza, 2012.

[5] Alcover de la Hera, C.M.; Martínez İñigo, D., Rodríguez Mazo,F., Domínguez Bilbao, R., "Introducción a la psicología del trabajo" Aravaca, Madrid : McGraw-Hill/Interamericana de España, D.L. 2007.

[6] Gil Rodríguez, F.; Alcover de la Hera, C.M. "Técnicas grupales en contextos organizacionales". Madrid : Pirámide, cop. 2004. 